\title{
Treatment of Oil Refinery Wastewater Using Pilot Scale Fed Batch Reactor Followed by Coagulation and Sand Filtration
}

\author{
Ghulam Shabir, Muhammad Afzal ${ }^{*}$, Razia Tahseen, Samina Iqbal, Qaiser M. Khan, Zafar M. Khalid \\ Soil \& Environmental Biotechnology Division, National Institute for Biotechnology \& Genetic Engineering (NIBGE), Faisalabad, \\ Pakistan \\ *Corresponding author: manibge@yahoo.com
}

Received December 22, 2012; Revised January 23, 2013; Accepted March 01, 2013

\begin{abstract}
The current study evaluates the performance of a pilot scale fed batch reactor (FBR), followed by coagulation and sand filtration, for the treatment of an oil refinery wastewater. The total reductions in COD, BOD, oil contents and phenol were $95.11 \%, 94.30 \%, 99.47 \%$ and $100 \%$, respectively, with FBR followed by coagulation and sand filtration. This FBR-coagulation-sand filtration treatment system also removed the toxicity from the oil refinery wastewater. Treated wastewater by this approach meets National Environ mental Quality Standards (NEQS) of Pakistan, and can be safely released into the environment.
\end{abstract}

Keywords: oil refinery wastewater, biological treatment, fed batch reactor, toxicity, coagulation, sand filtration

\section{Introduction}

Petroleum and its products are the dominant components of our modern industrial society. However, the refining of these fuels poses inevitable environmental risks [1]. The refin ing process consumes large amounts of water. Consequently, significant volumes of wastewater are generated [2], and globally this wastewater has been recognized as hazardous industrial waste as it contains toxic substances such as phenols, hydrocarbons and minerals $[3,4]$.

Currently different techniques, such as biological activated sludge, coagulation, electrocoagulation, adsorption and chemical oxidation, are being used for the treatment of oil refinery wastewater [5]. Biological treatment by fed batch reactor (FBR) is an option to remove organic pollutants from industrial effluent [6]. Coagulation and sand filtration can be applied to further enhance the removal of non-biodegradable pollutants from industrial wastewater [7]. In FBR, wastewater was slowly added into an aeration tank/reactor with no wastewater removal until tank is full. Although, FBR process is quite effective for the removal of pollutants from industrial wastewater [6,7], however, it is not evaluated for the treatment of an oil refinery wastewater.

The objective of the current study was to evaluate the performance of FBR at pilot scale followed by coagulation and sand filtration for the treatment of an oil refinery wastewater. Different pollution parameters (COD, BOD, oil and phenol) and toxicity of treated and untreated wastewater were determined to assess the potential of FBR-coagulation-sand filtration treatment system.

\section{Materials and Methods}

\subsection{Collection and Characterization of Wastewater}

Raw wastewater (without any primary treatment) used in this study was collected from an oil refinery, located in District Chakwal, Pakistan, and analyzed for various physico-chemical parameters (Table 1) using standard methods [8].

\subsection{Mixed Bacterial Culture Preparation}

Previously isolated and characterized oil-degrading bacterial strains, Pseudomonas putida 27, P. putida 6-B, $P$. putida 300-H, P. aeruginosa EBN-8, P. putida 300-B and $P$. putida 33, and phenol-degrading bacterial strains, $P$. aeruginosa and $P$. pseudomallei $[9,10]$, were subcultured on a separate nutrient agar plates and incubated at $37^{\circ} \mathrm{C}$ for 24 hours [10]. Separately, single colony of each bacterial strain was grown in Erlenmeyer flasks $(500 \mathrm{ml})$ containing $200 \mathrm{ml}$ of the nutrient broth mediu $\mathrm{m}(0.8 \%)$ and incubated for $24 \mathrm{~h}$ at $37^{\circ} \mathrm{C}$ on an orbital shaker at $120 \mathrm{rpm}$. Aliquots of culture medium $(150 \mathrm{ml})$ were centrifuged at $9820 \mathrm{~g}$ for $15 \mathrm{~min}$. The cell pellets were washed and resuspended in autoclaved normal saline $(0.9 \% \mathrm{NaCl}$ in distilled water). One hundred and twenty $\mathrm{ml}$ of each cell suspension was mixed to prepare mixed bacterial culture (1L), and used as inoculum in FBR operation.

\subsection{Pilot Scale Reactor}

Raw wastewater from an oil refinery, located in District Chakwal, Pakistan was used in this study. A pilot scale 
reactor consisting of a wastewater storage tank, biological reactor for FBR operation, alum treatment tank and sand filtration tank was used in this study as described earlier [7]. Biological reactor was made of glass container with a working volume of $200 \mathrm{~L}$ and covered with a stainless steel lid having options for air supply and temperature/pH probes. Sand filtration tank was a glass container with a sand bed of 3 inches. thickness at the bottom. Filling and withdrawing of wastewater was performed with the help of peristaltic pumps and mixing in biological and coagulation tank was carried out by overhead motor stirrers with stainless steel paddles (120rpm). A ir was purged in biological tank by an air compressor.

\subsection{Operational Conditions}

The following operating parameters were maintained during the biological-coagulation-sand filtration treatment of an oil refinery wastewater: 10h filling period, $24 \mathrm{~h}$ for aeration, 30min for each of settling, clarified liquid removal, coagulation and sand filtration process.

\subsection{Biological Treatment of Wastewater by FBR}

For FBR process, about $10 \mathrm{~L}$ of wastewater $(50 \%$ diluted with tap water), with required nutrients ( $\mathrm{N}$ and $\mathrm{P}$ ), was placed in the biological reactor and inoculated with $1 \mathrm{~L}$ bacterial consortium. The reactor was aerated for two days to obtain a dense culture. After two days, continuous feeding of the wastewater was started without any effluent removal. Temperature, $\mathrm{pH}$ and dissolved oxygen of the wastewater during operation were $30 \pm 2^{\circ} \mathrm{C}, 7.0 \pm 1$ and 3 $\pm 0.5 \mathrm{mg} \mathrm{L}^{-1}$, respectively. Samples collected after every $4 \mathrm{~h}$ for $24 \mathrm{~h}$ were analyzed for COD, BOD, oil and phenol contents. The reactor liquid volume increased linearly with time at a rate of $20 \mathrm{~L} \mathrm{~h}^{-1}$.

\subsection{Coagulation and Sand Filtration}

Biologically treated wastewater by FBR operation was treated with alu $\mathrm{m}$ for coagulation and then passed through sand bed as described earlier [7]. Biologically treated wastewater was left for $30 \mathrm{~min}$ for the settling of activated sludge (microorganisms, non-biodegradable materials). After settling, wastewater pumped into coagulation tank was mixed thoroughly with alum powder $\left(150 \mathrm{mg} \mathrm{L}^{-1}\right.$ of wastewater) for about $30 \mathrm{~min}$ at $120 \mathrm{rpm}$ and allowed to settle down again for $30 \mathrm{~min}$. The supernatant was passed through the freshly prepared sand bed under the force of gravity to remove the suspended particles. After each treatment of 200L biological and chemical treated wastewater, sand was cleaned by soaking in diluted sulfuric acid for overnight, then washing with tap water, and finally washing and soaking in distilled water. This sand was dried at $150^{\circ} \mathrm{C}$ and reused for filtration.

\subsection{Ecotoxicity Assays and Analytical Methods}

Acute toxicity of treated and untreated wastewater was determined by exposing fish (Labeo rohita) to the wastewater. The average weight and length of four months old fish were $1.6 \pm 0.3 \mathrm{~g}$ and $5 \pm 1 \mathrm{~cm}$, respectively. Before toxicity testing of every sample, $\mathrm{pH}$ of the wastewater was adjusted to $7.0 \pm 0.5$ with $\mathrm{HCl} / \mathrm{NaOH}$. The wastewater was then placed in water bath to bring its temperature to $22^{\circ} \mathrm{C}$. For each treatment five fish were transferred to aerated aquaria containing 10L tap water (control), treated and untreated wastewater in triplicate. The mortality data of fish were recorded for $72 \mathrm{~h}$. As per requirement of the test, no feed was supplied to the experimental fish; the aeration however was supplied continuously till the end of experiment. Dead fish, if any, were immediately removed from each tank. [7]. The COD, BOD, oil, phenol and toxicity were determined using standard methods [8].

\section{Results and Discussion}

\subsection{Effluent Characterization}

Physico-chemical characterization of oil refinery wastewater (ORW) revealed that it contained higher concentrations of COD, BOD, oil, phenol, TDS, TSS, chlorides, iron, copper and zinc than the wastewater discharge standards of Pakistan [11] as shown in Table 1.

Table 1. Physico-chemical characte rization of oil refinery wastewater

\begin{tabular}{|c|c|c|c|}
\hline Parameters & Units & Wast ewat er values & NEQS values \\
\hline $\mathrm{pH}$ & -- & $8.31(1.4)$ & $6-10$ \\
\hline $\begin{array}{c}\text { Electrical } \\
\text { conductivity (EC) }\end{array}$ & $\mathrm{mS} \mathrm{cm}^{-1}$ & $9.43(2.86)$ & NG \\
\hline $\begin{array}{c}\text { Chemical oxygen } \\
\text { demand (COD) }\end{array}$ & $\mathrm{mg} \mathrm{L}^{-1}$ & 1965 (175) & 150 \\
\hline $\begin{array}{c}\text { Biochemical oxygen } \\
\text { demand (BOD) }\end{array}$ & $\mathrm{mg} \mathrm{L}^{-1}$ & $685(84)$ & 80 \\
\hline $\begin{array}{c}\text { Total dissolved solids } \\
\text { (TDS) }\end{array}$ & $\mathrm{mg} \mathrm{L}^{-1}$ & $6267(548)$ & 3500 \\
\hline $\begin{array}{l}\text { Total suspended } \\
\text { solids (TSS) }\end{array}$ & $\mathrm{mg} \mathrm{L}^{-1}$ & $315(32)$ & 150 \\
\hline Oil contents & $\mathrm{mg} \mathrm{L}^{-1}$ & $1057(89)$ & 10 \\
\hline Phenol & $\mathrm{mg} \mathrm{L}^{-1}$ & $18.32(3.70)$ & 0.1 \\
\hline Nitrogen & $\mathrm{mg} \mathrm{L}^{-1}$ & $0.15(0.01)$ & $\mathrm{NG}$ \\
\hline Phosphorous & $\mathrm{mg} \mathrm{L}^{-1}$ & $0.67(0.05)$ & $\mathrm{NG}$ \\
\hline Chlorides & $\mathrm{mg} \mathrm{L}^{-1}$ & $2575(349)$ & 1000 \\
\hline Sulfate & $\mathrm{mg} \mathrm{L}^{-1}$ & $137(25.3)$ & 600 \\
\hline Total hardness & $\mathrm{mg} \mathrm{L}^{-1}$ & $985(46)$ & NG \\
\hline Calcium & $\mathrm{mg} \mathrm{L}^{-1}$ & $84(7.4)$ & NG \\
\hline Magnesium & $\mathrm{mg} \mathrm{L}^{-1}$ & $61(8.2)$ & $\mathrm{NG}$ \\
\hline Sodium & $\mathrm{mg} \mathrm{L}^{-1}$ & $3369(390)$ & $\mathrm{NG}$ \\
\hline Potassium & $\mathrm{mg} \mathrm{L}^{-1}$ & $80(18.5)$ & $\mathrm{NG}$ \\
\hline Iron & $\mathrm{mg} \mathrm{L}^{-1}$ & $6.48(0.47)$ & 1 \\
\hline Copper & $\mathrm{mg} \mathrm{L}^{-1}$ & $4.72(0.32)$ & 1 \\
\hline Zinc & $\mathrm{mg} \mathrm{L}^{-1}$ & $4.3(0.38)$ & 1 \\
\hline
\end{tabular}

Each value is the mean of six replicates; the standard deviation of 6 different samples collected at different time intervals is presented in parentheses. NEQS: National Environmental Quality Standards.

\subsection{Performance of FBR Operation}

The COD, BOD, oil and phenol removal by FBR operation is presented in Figure 1. Initially pollutant removal was slow but as the reactor established, enriched bacterial population enhanced the pollutant removal from the wastewater.

FBR was proven to be highly efficient in removing COD and BOD (84.47\% and $85.69 \%$, respectively). The significant removal of COD and BOD could be attributed to the enrichment of pollutant-degrading bacteria in diluted $(50 \%)$ oil refinery wastewater for two days, possibly enhanced acclimatized bacterial population 
degrade the organic pollutants more efficiently. Furthermore, biological processes were enhanced due to aeration which assisted in microbial degradation of organic matter in wastewater by the oxidation process [12]. Treatment of wastewater containing high amount of organic matter is accomplished through several, physical, chemical and biological processes. However, aerobic microbial degradation is the main mechanism of detoxification. In this study, COD removal $(84.47 \%)$ by FBR was higher than previously reported COD removal from oil refinery wastewaters using different biological reactors $[12,13]$.



Figure 1. Degradation of COD, BOD and oil contents by FBR operation at pilot scale reactor. Bars are indicating standard error of three react or operations.

The FBR operation also exhibited high efficiency to remove oil contents from wastewater. This might be due to the fact that the applied bacterial strains possessing high capability to degrade different types of hydrocarbons present in petroleum oil [10].

Oil degradation was started during the first four hours of operation and continued up to $20 \mathrm{~h}$, resulting in $81.07 \%$ reduction in oil contents by FBR. However, phenol was completely removed from the oil refinery wastewater within $20 \mathrm{~h}$ (data not shown).

Table 2.COD, BOD, oil and phenol reduction in oil refinery wastewate $r$ by fed batch reactor (FBR) followed by coagulation (CT) and sand filtration (SF)

\begin{tabular}{|c|c|c|c|c|}
\hline $\begin{array}{c}\text { Parameter } \\
\left(\mathrm{mg} \mathrm{L}^{-1}\right)\end{array}$ & Inlet & $\begin{array}{c}\text { FBR } \\
(24 \mathrm{~h})\end{array}$ & $\mathrm{CT}+\mathrm{SF}$ & Total removal (\%) \\
\hline COD & $1965(175)$ & $305(65)$ & $96(14)$ & 95.11 \\
\hline BOD & $685(84)$ & $98(38)$ & $39(1.9)$ & 94.3 \\
\hline Oil & $1057(89)$ & $200(31)$ & $5.5(1.5)$ & 99.47 \\
\hline Phenol & $18(3.7)$ & 0 & 0 & 100 \\
\hline
\end{tabular}

Each value is a mean of three different react or operations and values in parentheses indicates st andard error among them.

These results are in agreement with the study of Jou and Huang [14], who reported the complete removal of phenol from an oil refinery wastewater using fixed film bio reactor. However, in this study, phenol removal $(100 \%)$ by FBR was higher than reported by Freire et al, [13]. They reported $65 \%$ phenol removal (at concentration of $4.3 \mathrm{mg}$ $\mathrm{L}^{-1}$ ) from an oil refinery wastewater by using sequencing batch reactor $(\mathrm{SBR})$.

\subsection{Effect of Coagulation and Sand Filtration}

FBR treated wastewater was further subjected to coagulation and sand filtration, it resulted in additional reduction in COD, BOD and oil contents (Table 2). The significant removal of organic pollutants from wastewater by coagulation and sand filtration might be due to that coagulants broke the stability of colloidal particles and emu lsified oil in wastewater. The organic pollutants levels in the final effluent indicate that the co mbined coagulation and sand filtration have potential to remove less biodegradable and/or non-biodegradable organic pollutants from the wastewater $[7,15]$.

\subsection{Ecotoxicity}

Biological treatment in FBR process followed by coagulation and sand filtration removed the toxic pollutants from the oil refinery wastewater, for this given condition. Fish exposed to untreated wastewater died immediately, while the fish exposed to treated wastewater showed survival for the studied time period (Table 3 ). Previously it was also reported that oil refinery wastewater showed lethal effects on fish [16]. The detoxification of oil refinery wastewater by FBR-coagulation-s and filtration indicating that not only original toxicity was removed but metabolites produced during biodegradation also had no toxic effects.

Table 3. Mortality of fish at different concen trations of untreated and treated oil refinery waste water (ORW)

\begin{tabular}{|c|c|c|c|c|c|c|}
\hline & \multicolumn{2}{|c|}{$24 \mathrm{~h}$} & \multicolumn{2}{c|}{$48 \mathrm{~h}$} & \multicolumn{2}{c|}{$72 \mathrm{~h}$} \\
\hline Treatments & Dead & Alive & Dead & Alive & Dead & Alive \\
\hline Tap water & 0 & 5 & 0 & 5 & 0 & 5 \\
\hline Untreated ORW $W$ & - & - & - & - & - & - \\
\hline Undiluted & - & 4 & 2 & 3 & 3 & 2 \\
\hline $50 \%$ diluted & 1 & 4 & 1 & 4 & 2 & 3 \\
\hline 25\% diluted & 1 & & & & \\
\hline Treated OR $W$ & & 5 & 0 & 5 & 0 & 5 \\
\hline Undiluted & 0 & 5 &
\end{tabular}

\section{Conclusions}

This study reveals that significant removal of pollutants from oil refinery wastewater could be achieved by fed batch reactor. Furthermore, less biodegradable and/or nonbiodegradable pollutants can be removed by treating biological treated wastewater with alum and then filtering through the sand bed. This technique could be applied for the removal of organic pollutants and toxicity from the industrial effluent.

\section{Acknowledgment}

The authors are grateful to all the personnel of Oil and Gas Development Company Limited (OGDCL) Chakwal, Pakistan for providing as sistance during sample collection.

\section{References}

[1] Peña-Castro, J.M., Barrera-Figueroa, B.E., Fernández-Linares, L., Ruiz-Medrano, R and Xoconostle-Cázares, B, "Isolation and identification of up-regulated genes in bermudagrass roots (Cynodon dactylon L.) grown under petroleum hydrocarbon stress", Plant Science, 170 (4). 724-731. April 2006. 
[2] Coelho, A., Castro, A.V., Dezotti, M. and Sant'Annar Jr, G.L, "Treatment of petroleum refinery sourwater by advanced oxidation processes", Journal of Hazardous Materials, 137(1). 178-185. September 2006.

[3] Nations Industrial Development Organization (UNIDO), The United Nations System in Pakistan Islamabad. Publication No. UN-PAK/98/006/09/UNIDO/2001/1. 2001.

[4] Zhao, X., Wang, Y., Ye, Z., Borthwick, A.G.L. and Ni, J, "Oil field wastewater treatment in biological aerated filter by immobilized microorganisms", Process Biochemistry, 41(7). 1475-1483. July 2006.

[5] Rahman, M.M. and Al-Malack M.H, "Performance of a crossflow membrane bioreactor (CF-MBR) when treating refinery wastewater", Desalination, 191(1-3). 16-26. May 2006.

[6] Moreno-Andrade, I., Buitron, G.N., Betancur, M.J. and Moreno, J.A, "Optimal degradation of inhibitory wastewater in a fed batch bioreactor", Joumal of Chemical Technology and Biotechnology, 81(4). 713-720. April 2006.

[7] Afzal, M., Shabir, G., Hussain, I. and Khalid, Z.M, "Paper and board mill effluent treatment with the combined biologicalcoagulation-filtration pilot scale reactor", Bioresource Technology, 99(15). 7383-7387. October 2008.

[8] Eaton, A.D., Clesceri, L.S. and Greenberg, A, Standard methods for the examination of water and wastewater, American Public Health Association. Washington DC, 1995.

[9] Afzal, M., Iqbal, S., Rauf, S. and Khalid, Z.M, Characteristics of phenol biodegradation in saline solutions by monocultures of
Pseudomonas aenuginosa and Pseudomonas pseudomallei, Journal of Hazardous Materials, 149 (1). 60-66. Oct ober 2007.

[10] Shabir, G., Afzal, M., Anwar, F., Tahseen, R. and Khalid, Z.M "Biodegradation of kerosene in soil by a mixed bacterial culture under different nutrient conditions", International Biodeterioration and Biodegradation, 61(2). 161-166. March 2008.

[11] NEQS (National Environmental Quality Standards) for Municipal and Liquid Industrial Effluents, Islamabad, Pakistan, Revised December 28, 1999.

[12] Primasari, B., Ibrahim, S., Annuar, M.S.M. and Remmie, L.X.I, Aerobic treatment of oily wastewater: Effect of aeration and sludge concentrat ion to pollutant reduction and PHB accumulation, World Academy of Science, Engineering and Technology, 78. 172175. 2011.

[13] Freire, D., Cammarota, M. and Sant'Anna, G, Biological treatment of oil field wastewater in a sequencing batch reactor, Environmental Technology, 22(10). 1125-1135. May 2001.

[14] Jou, C.J.G. and Huang, G.C, A pilot study for oil refinery wastewater treatment using a fixed-film bioreactor, Advances in Environmental Research, 7(2). 463-469. January 2003.

[15] Rodrigues, A.C., Boroski, M., Shimada, N.S., Garcia, J.C., Nozaki, J. and Hioka, N, Treatment of paper pulp and paper mill wastewater by coagulation-flocculation followed by heterogeneous photocatalysis, Journal of Photochemistry and Photobiology A: Chemistry, 194(1). 1-10. 2008.

[16] Wake, H, Oil refineries: A review of their ecological impacts on the aquatic environment, Estuarine, Coastal and Shelf Science, 62(1-2). 131-140. January 2005. 